\author{
N. BOLOHOVA, I. RUBAN
}

\title{
IMAGE PROCESSING MODELS AND METHODS RESEARCH AND WAYS OF IMPROVING MARKER RECOGNITION TECHNOLOGIES IN ADDED REALITY SYSTEMS
}

The subject matter of article is method of image processing, which identify and describe the local features of images. The aim of the article is the determination of ways for interconnection of the methods for processing the image and technologies creation in the development of markers in the systems of additional reality. The following tasks are solved in the article: to analyze the existing methods and algorithms for finding objects in two-dimensional images to determine the basic marker recognition technology in the complementary reality systems. Analyzed genetic, neural network, statistical and fractal methods, as well as approaches to the algorithms implementation of in the software construction for systems of complementary reality. The next results were obtained: a review and a comparative analysis of the main known algorithms for detecting key points in the images were conducted. It was suggested in the development of marker recognition methods it is necessary to develop a procedure of preliminary image processing for the formation algorithms of the front image for the marker under different conditions of obtaining images. At segmentation stages, it is expedient to use genetic algorithms based on the best indicators of proper segmentation and low processing time, but it is necessary to develop functions that are appropriate for the format of the markers. Improve existing methods for processing segmentation results based on a criterion base describing a visual model representing a marker. Conclusions: as a result of the analysis, the following conclusion can be drawn. The fastest and the most accurate algorithm for putting key points is the genetic algorithm (average time of the algorithm is 5.23 seconds, the number of correct answers is 84.25). The longest working time is the neural network method -8.45 seconds, the accuracy of this algorithm is also the lowest -52 . Another advantage of the algorithm of point matching is that if the object goes beyond the frame and then returns again, the program will again continue to track this object. This is supported by algorithms of machine learning. You can also notice that the SIFT calculation works much faster than fractal texture analysis. These results suggest that there are currently no methods for recognizing markers, allowing high accuracy of less than one unit to recognize in a short time. In our opinion, one of the promising directions is the use of Royan methods, namely the development of target functions for accurate and fast recognition of the image by markers.

Keywords: augmented reality; marker; non-marker technology; descriptor; reference points; Charis Corner Detector; genetic algorithms; neuron network; SIFT.

\section{Introduction}

The technology of augmented reality becomes more and more popular every day and can be used in various fields of activity, such as computer games, tourism, shopping, gadgets, social networks, military affairs and even furniture collection, and will allow making various tasks easier and more functional.

Augmented reality (AR) is a technology that allows you to overlay the real world of digital data and messages about the object being studied using the computer devices.

Models and methods of applying the technologies of the augmented reality allow expanding the possibilities for user interaction with the software. Apps are not only entertaining, but also serve as a visual representation of something complicated. But at the moment the possibilities of this technology are not fully disclosed [1].

The use of augmented reality technology allows you to quickly access additional product information such as visual (3D images), audio or text. As an example, it may be the company logo, geometric image, text information, presentation of the product, etc. [2].

\section{Analysis of marker recognition technologies}

The augmented reality marker is an object (image) that is an identifier for activating the display of additional information. A generalized marker recognition algorithm is depicted as a flowchart in fig. 1.

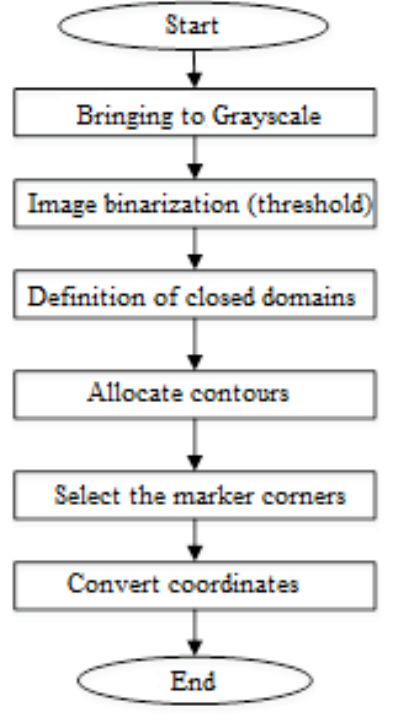

Fig.1. A generalized marker recognition algorithm

It is possible to distinguish two main principles of construction of the augmented reality:

- Marker technologies, in which the marker usually has a contrasting high-resolution picture frame with an image inside.

- Markerless technologies which is based on the user location coordinates or based on reference points (markers) of the image.

Schematic search methods for markers are presented in fig. 2 . 


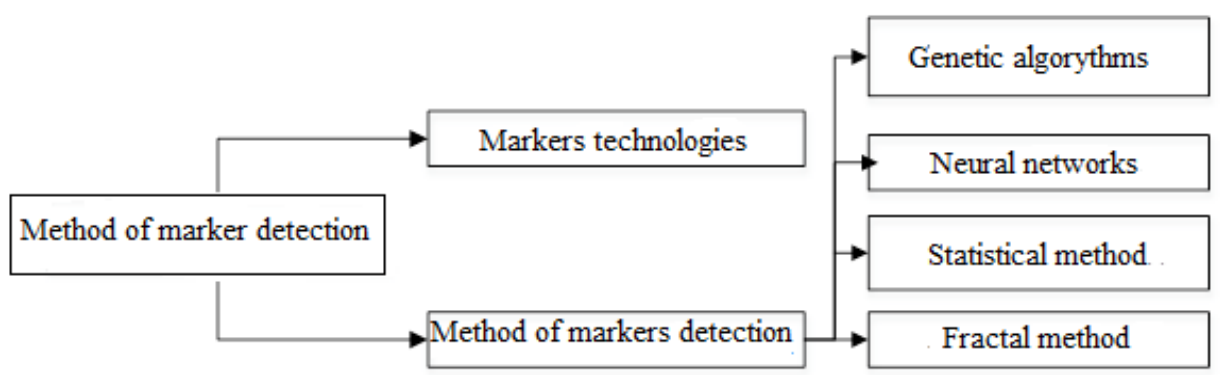

Fig. 2. The main methods of detecting markers

In order to ensure the consistent recognition of markers. Conduct an analysis of methods and algorithms for searching objects in a two-dimensional image based on image segmentation technologies according to the classification criteria and provide recognition procedures.

The purpose of this article is to determine the ways of improving the methods of image processing in marker recognition technologies in complementary reality systems.

The following tasks are solved in the article:

1) to analyze the technology of constructing markers;

2) to carry out analysis of markers and segmentation of images in the part of image segmentation by local attributes;

3) to identify ways to improve marker recognition methods in complementary reality systems.

\section{Analysis of image processing methods in terms of segmentation}

At the basis of non-marker technologies there are the recognition algorithms, with which the virtual grid is superimposed on the surrounding terrain shot by the camera. On this grid, the software algorithms have certain points that determine the exact location to which the virtual model will be tied.

The main requirement for an image in non-marker technologies is the contrast of the picture. If this condition is met, a logo, a photograph and a landscape any image can be used to bind objects of augmented reality [3].

One of the main problems is the separation of the false image point from the real ones when tracking the motion of the camera or when reconstructing the threedimensional scene. It is complicated by the fact that it is impossible to reliably solve it, working with only one image. It is necessary to establish a match between the features of several images, and then build a model to which these matches will satisfy the best. Special points, the conformity of which will not satisfy the model, will be considered false, or as emissions [4].

Most of the algorithms for finding point features work on the same principle: for each point of the image, some function is calculated from its boundary. The points in which this function reaches a local maximum can be distinguished from all points with some of its boundary.

There are three basic approaches to determining the local features of an image:
1. Based on image brightness: special points are calculated directly from the intensity values of the pixels of the image.

2. Image contours are used: methods extract contours and look for places with the maximum value of curvature or make the approximation of contours and determine the intersection. Such methods are sensitive to cross-border sections, since the extraction can often be incorrect in those places where 3 or more edges intersect.

3. Based on the use of the model: intensive models are used as parameters adapted to image-patterns to subpixel precision. They have a limited application with special points of special types (for example, L-connecting angles) and depend on the patterns used.

In practice, the methods based on the brightness of the image are mostly used for a wide application [5].

Advantages of non-marker technology:

- Any objects of the real world in the image may act as markers and do not need to create special visual identifiers for them;

- A "live 3D label" can be any graphic image applied to any surface, for example, paper, plastic or other material, not necessarily a picture inside the graphic frame;

- Practically any black-and-white or full-color images, various objects such as the face, hands, and even the human body can be the markers from which the information is read.

Disadvantages of non-marker technology:

- high-quality (contrast) high-resolution images are required;

- separating the erroneous features from the present while monitoring the movement of the camera;

- it is necessary to use a series of images to more accurately build reference points.

\section{Genetic algorithm:}

Genetic algorithm (GA) is an adaptive method of search, based on the selection of the best elements in the population, similar to the principles of evolution [6].

When using genetic algorithms for solving the optimization problem it is necessary:

1. Determine the number and type of task variables that need to be encoded in the chromosome.

2. Determine the criterion for assessing individuals by setting the fitness function (target function).

3. Select the coding method and its parameters.

4. Determination of parameters of GA (population size, type of selection, genetic operators and their probability, the amount of breaks in generations). 
The parameters of GA, defined in paragraph 4 (as well as, sometimes, in paragraphs 2 and 3), are characterized by the method of checking variants, based on the analysis of the results obtained. To analyze the results of GA work it is necessary to conduct several algorithm launches.

In fig. 3 the general scheme of problem solving using $\mathrm{GA}$ is given

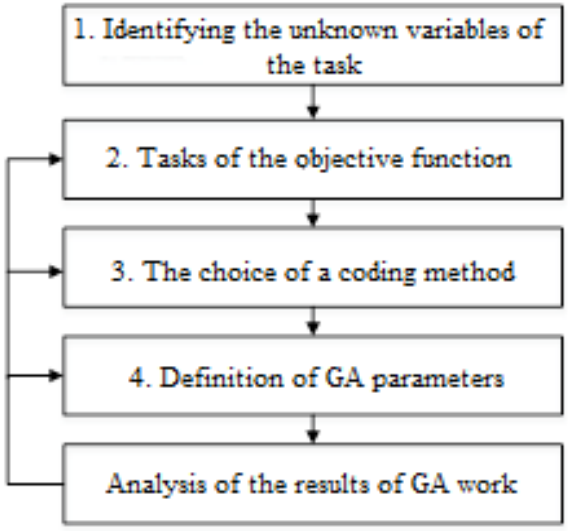

Fig. 3. General scheme of task solving using GA
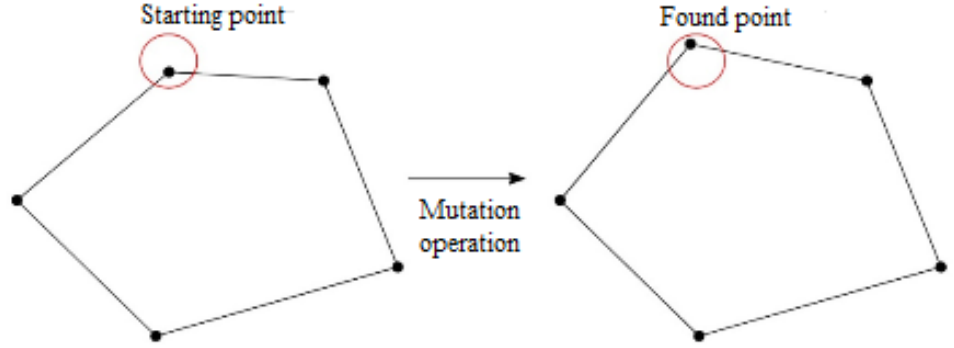

Fig. 4. Example of mutation of the contour

Two types of crossover are implemented:

1. Both parents are cut at some arbitrary point, then the parts of one of the parents are connected with parts of another and a new organism appears. This crossover is
To solve the problem of finding reference points (markers) it is necessary to redefine the standard notions and operations of the genetic algorithm. Points will be taken as genes. Then the genotype will be the set of all possible points on the depicted.

Proceeding from the fact that the points are genes, the sets of genes, that is, individuals will be snakes: they are represented as sets of points and, accordingly, are suitable for this role. Snakes will also be characterized by a set of components that are similar to those that have contours in Active Contours [7].

Consider the principles of GA:

1. A set of genes $g_{i}, i=\overline{0, n-1}$ is a set of points, the location of which in the image shows the phenotype of the snake - its location in the image.

2. The value of the fitness function.

The population is defined as a set of snakes. The mutation operation for the point to be mutated will look like this: a different point is selected from a predefined boundary if a new point is in the image, and then the starting point is replaced by the found (fig. 4). In the case when the found point is not within the image, a new point is re-searched.
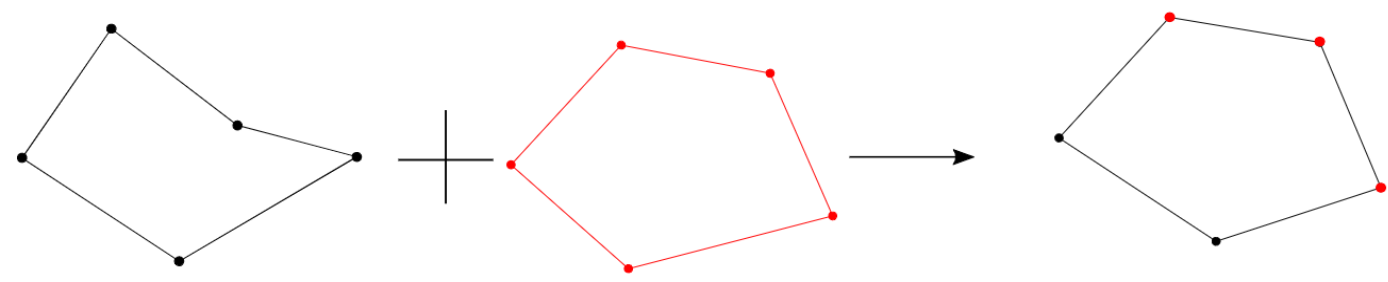

Fig. 5. Example of the implementation of the "one point" crossover

2. The only descendant with a certain probability is assigned the genes of one of the parents. This type of crossover is called "uniform" (fig. 6). It is notable that it

called one-point crossover, and it is sometimes referred to as a crossover based on "cut and connect" (CutandSplice) (fig. 5);

simulates the action of all possible types of crossover based on "cutting and joining," giving much more variation [8].
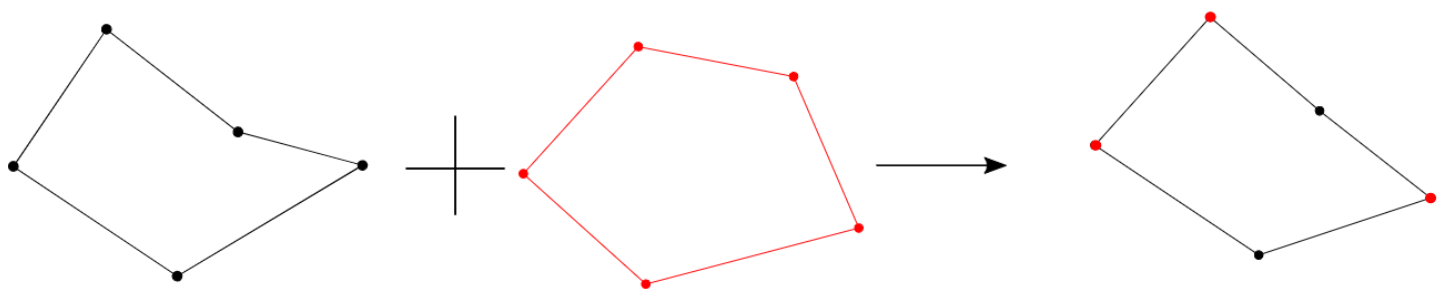

Fig. 6. An example of a "uniform" crossover 
Species selection can be implemented using the "Tournament" method. The idea of this method is that for the selection of each candidate there are several "tournaments" (from 1 and more), each of which randomly chooses one individual population; in order to then compare its suitability with that which was chosen earlier.

As a function of the adaptation, the modified energy functional proposed in [8] is used. It should be noted that the original image is reduced to a type in gray scale, after which the Gauss filter is narrowed. The result of the search for the reference points (markers) is presented in fig. 7.

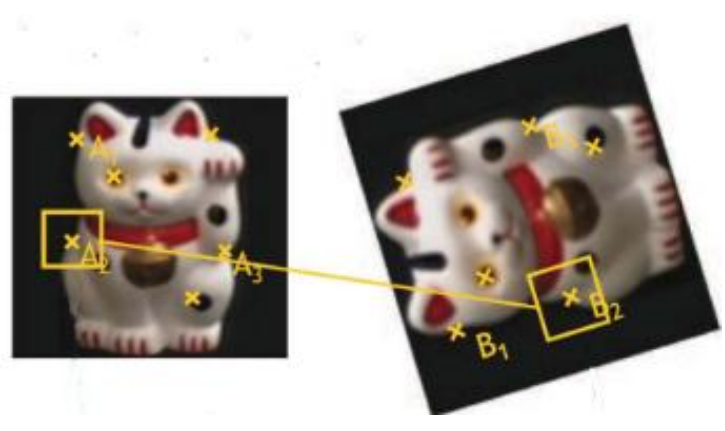

Fig. 7. The result of the genetic algorithm operation [8]

Advantages of the genetic algorithm:

- GAs work with codes that represent a formalized set of parameters, which are the arguments of the target function. In the process of GA manipulation with codes occur regardless of their semantic content, that is, the code is considered simply as a bit string.

- When implementing the GA search procedure, several points of the search space are processed simultaneously, but do not move sequentially from point to point, as in traditional methods. This approach allows overcoming the danger of falling into the local extremum of the polymodal target function. The use of multiple points at the same time greatly reduces the likelihood of a similar event.

- In the course of the work of the GA, they do not use additional information, except for data on the area of admissible values of parameters and the target function at any point, which increases the speed of their work.

- To generate new points of the search space at the same time, GA uses both probabilistic and deterministic rules, which gives a much greater effect than each of these methods separately.

- Disadvantages of the Genetic Algorithm:
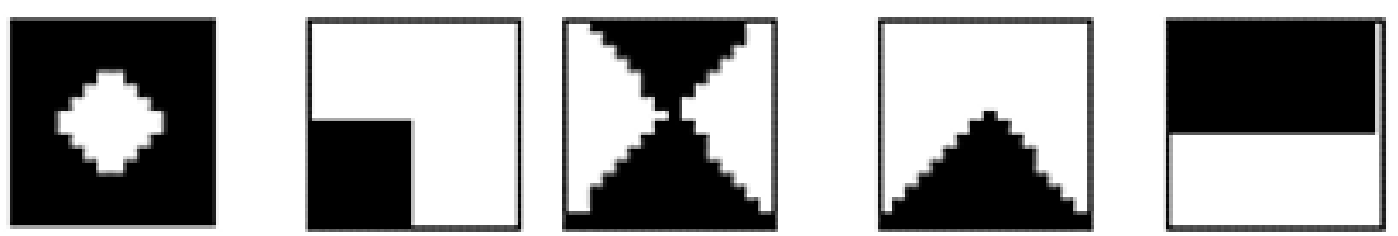

Fig. 8. Examples of target area templates

In the process of recognition, the point with its border of $16 \times 16$ pixels is fed to the input of the neural network and evaluated the output at the output. The experiments given in the article [10] show that learning
- The optimal solution is not guaranteed.

- It is only the specialist who can effectively formulate the task, determine the criteria for selecting chromosomes (specify the code) and other parameters of the GA.

- The rather high computational complexity of GA leads to the fact that during the modeling of evolution, many decisions are rejected as unpredictable.

- The time complexity is, on average, lower than that of the best competing algorithms, but no more (obtained from experimental data) than one order.

- Low efficiency in the final stages of evolution modeling is explained by the fact that GA search mechanisms are not strictly focused on fast access to the local optimum prime.

- Some other issues have not been resolved, such as the problem of self-adaptation of GA.

\section{Neural networks:}

Marker recognition is the most complex process, because it means scanning all combinations of reference points on the images and matching them with the marker. Often, the quality of recognition depends on the effectiveness of many processes, ranging from the process of entering the image and ending with the formation of reference points. Therefore, it makes sense to limit the scope of interest in large-sized images. As areas used to compare markers, points were selected with the largest difference of gradient brightness. The most striking example of special points is the angles in the picture of the scene. They were determined by comparison with the standard. All the boundary points were compared with the standards for finding the most similar.

The search for corner points can be realized within the framework of different approaches, taking into account the size of the found areas and their orientation. An example is the Harris angle detector [9], which is based on the study of monotony of image areas. However, since the entire system is formed with a neuronbased solution to the problem, it is possible to use the Hopfield neuron network and the network of radial neurons to accelerate and simplify the search. When studying both networks, samples of angles, straight edges and monotonous regions, turned at different angles, were used. Examples of samples are shown in fig. 8, which shows 5 out of 55 accepted standards for processing. Each benchmark is represented by a binary matrix of $16 \times 16$ pixels. 
the calculation of the Euclidean norm of distance from the region around the point, which is investigated to all the standards according to the following scheme:

$$
d\left(p, d_{j}\right)=\sqrt{\sum_{k=1}^{n=256}\left(p_{k}-b_{j k}\right)^{2}},
$$

where

$$
p=\left\langle a_{1,1}, a_{1,2}, \ldots, a_{1,16}, a_{2,1}, \ldots, a_{2,16}, \ldots, a_{16,16}\right\rangle
$$

vectorized matrix of the region around the point; $a_{j k}[0,1]$ - the binary value of the pixel in the investigated area closed to the interval $[0,1]$; $q_{j}=\left\langle b_{j 1,1}, b_{j 1,2}, \ldots, b_{j 1,16}, b_{j 2,1}, \ldots, b_{j 2,16}, \ldots, b_{j 16,16}\right\rangle ; \quad b_{j k}=[0,1] \quad-$ binary pixel value in the reference area.

If the minimum Euclidian distance is achieved when compared with patterns, corresponding angular peculiarities, then the point is considered special, otherwise it is shifted away. After determining the set of singular points, their coordinates are recalculated in relation to the scale of the original, not yet compressed image. The time of comparison with the standards in the network of radial neurons does not exceed $20 \ldots 30 \mathrm{~s}$, which suggests its advantage. In addition, the number of corner areas allocated in this way is much larger than that of Hopfield networks [11].

Fig. 9 shows the processing of the frame - the search for key points.

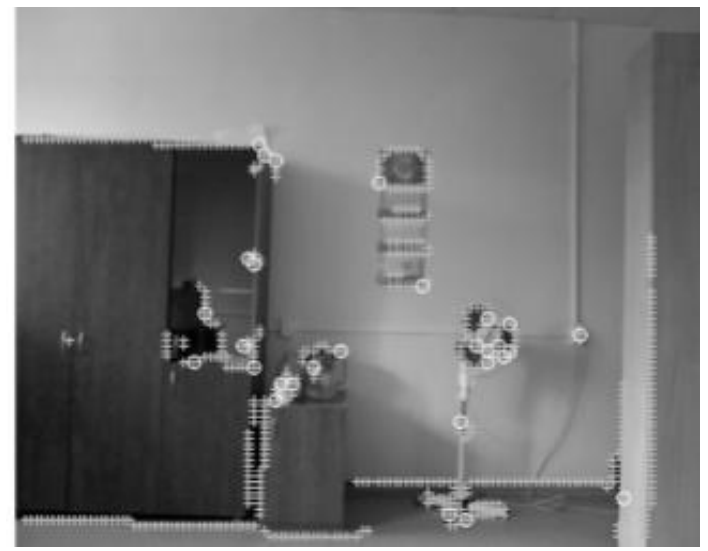

Fig. 9. Selection of key points in an image using a network of radial neurons [12]

\section{Advantages of the neural network:}

- The developed algorithm provides a comparison of special points (markers) with high accuracy, which allows reducing the errors of the following stages of the complemented reality.

- The process of creating a neural network relates more to the learning process than to the programming.

Disadvantages of Neural Network:

- Areas with a monotonous intensity change do not allow performing procedures for comparing projection images of scene points.

- Mathematical problems related to learning: getting into a local optimum, choosing the optimal optimization step, re-training.
- It is difficult to formalize the stage of choosing the network architecture (number of neurons, layers, and the nature of links).

- The size and type of input signals exactly coincide with the dimension and type of output signals. This significantly restricts the use of the network in the task of marking recognition.

\section{SIFT:}

Consider how special points are highlighted by the SIFT method. The main aspect in their finding is the construction of the Gaussian pyramid and the differences of the Gaussians. Gaussian is an image that was blurred by the Gaussian filter. It turns out as follows:

$$
L(x, y, \sigma)=G(x, y, \sigma) * I(x, y) .
$$

In the formula (2) $L(x, y, \sigma)-$ this is the Gaussian value at the coordinate point $(x, y)$ and the radius of blurring $\sigma, G(x, y, \sigma)$ - Gass kernel, $I(x, y)$ - the value of the original image. It is worth noting that the Gass kernel does not multiply at the value of the original image, between them there is a convolution operation.

The Gaussian difference is called the image obtained by pixel-by pixel deducing the Gaussian image of the original Gaussian image, which has another radius of blurring (we denote it as $\kappa \sigma$ ):

$$
D(x, y, \sigma)=L(x, y, k \sigma)-L(x, y, \sigma) .
$$

Next, the Gaussian pyramid is built. To do this, the entire scalable space (sets of different variations of the original image, smoothed by any filter) is divided into areas called octaves. There is a nuance that consists in the fact that the part of the scaling of space occupied by the next octave should be twice that of the part that was engaged in the previous one. Yes, and when moving from one octave to the next image size, the image is reduced twice. It is clear that any octave will cover an infinite number of Gaussian images, so they are limited only to a certain number of $N$ with a certain step in the radius of blurring. Next, two more Gaussians are being completed, which extend beyond the octave (this is done in order to be able to check the image for the presence of extremum). The magnitude of the first image of the next octave is equal to the scale of the image from the previous octave with the number [13].

At the same time both the Gaussians pyramid and the Gaussian pyramid of differences will be built, the number of images in which will be one less than in the first (fig. 10).

After building the pyramids, special points are determined. A point is considered to be special if it is a local extremum of the Gaussian difference (fig. 11).

If the value of differences between the Gaussians at the point indicated by the cross is less or more than all of the values at the points indicated by the circle, then this point is an extremum point, that is a special point. That is, each point of the current image Gaussians difference compared to its neighboring eight points and nine neighboring points on the senior and junior levels in the pyramid. That is why we need two additional Gaussians 
so that we could search for the local extremums for the

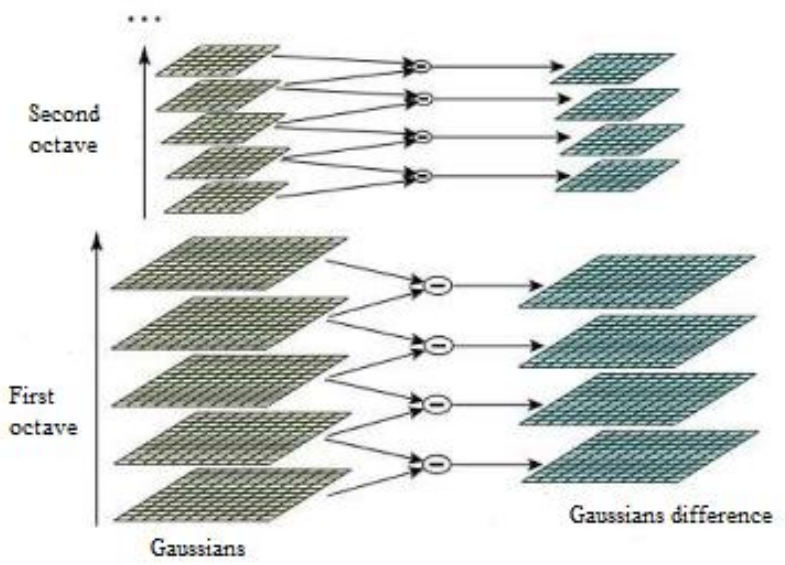

Fig. 10. Getting the Gaussian and the Gaussian difference Pyramids

Advantages of the SIFT statistical method:

1. Accuracy, stability, invariance to scale and rotation and displacement.

2. The SIFT method allows you to compare images subjected to such transformations as zooming, moving objects on the scene, turning the camera or object.

3. The SIFT algorithm works with binary images

Disadvantages of the statistical method SIFT:

1. After searching for special points, the action does not end. Next, they are checked, since not all of these points are suitable for further work in the algorithm. To do this, you need to determine the coordinates of a special point with increased accuracy.

2. It requires a lot of hardware resources for normal operation in real time.

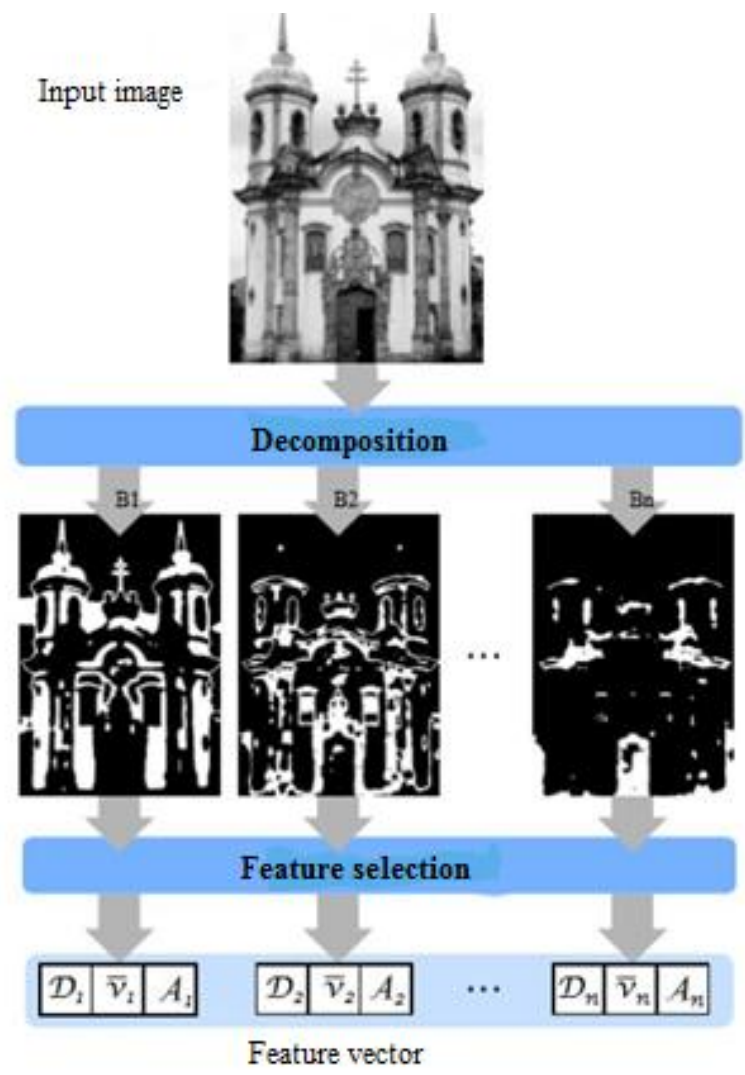

first and last image [14]

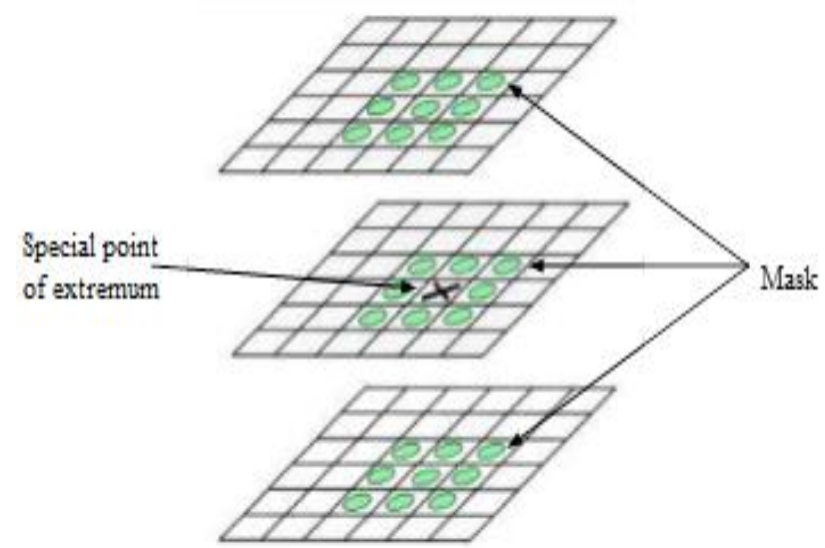

Fig. 11. Determination of a special point on a local extremum

3. Mathematical analysis shows that the application of the SIFT algorithm allows you to determine the coordinates of a location with an error of no more than one meter, regardless of time.

4. Not all received points and their descriptors will meet the stated requirements and this may affect the further solution of the problem.

Segmentation fractal texture analysis:

The algorithm for segmentation fractal analysis is intended to construct a space of signs of presentation of the texture of image I. The input of the algorithm is a halftone image and a certain parameter.

The structure of the segmentation fractal analysis algorithm is presented in fig. 12 .

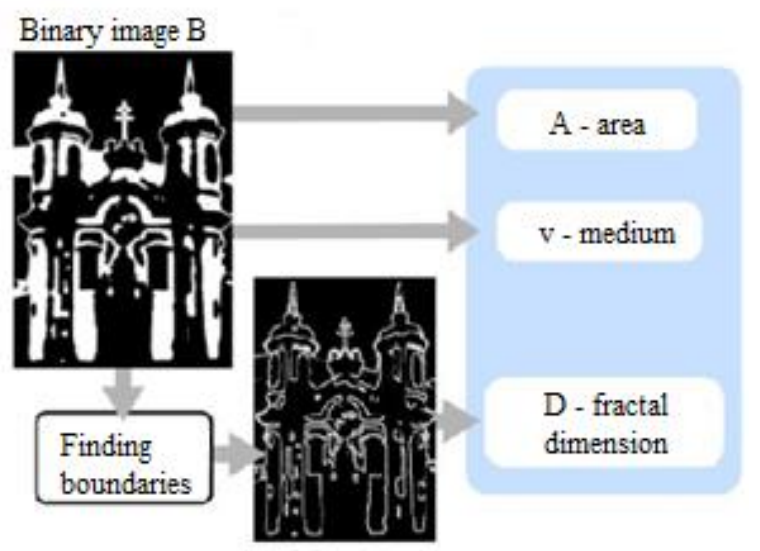

Fig. 12. The structure of the segmentation fractal analysis algorithm [16] 
In the first step, you need to segment the image by brightness levels. To find the thresholds for segmentation, we will use the multilevel algorithm of the Father [15]. The idea of the Father's algorithm is to split the image into two regions in such a way as to minimize the intraoral variance. Applying this algorithm recursively, we obtain a set of threshold values. The number of requested thresholds is indicated $n_{t}$ and is the input parameter of the algorithm. The set of thresholds $T$ is supplemented with the brightest pixel value in the image $T=\left\{t_{i}\right\} \bigcup n_{l}$. Next, using the found threshold values, we obtain a set of binary images $\left\{B_{i}\right\}$

$$
B_{i}(x, y)=\mid \begin{aligned}
& 1, i f, I(x, y) \geq t_{i} \\
& 0, \text { else }
\end{aligned} .
$$

For all images with $\left\{B_{i}\right\}$ construct contour images $\left\{G_{t}\right\}$. In the formula $N_{8}[(x, y)]$ - set of pixels, which is in relation to the 8-connection with $(x, y)$. On the received images we find the following values (5).

$$
G_{i}(x, y)=\mid \begin{aligned}
& 1, i f, \exists(\bar{x}, \bar{y}) \in N_{8}[x, y]: B_{i}(\bar{x}, \bar{y})=0 \wedge B_{i}(x, y)=1 \\
& 0, \text { else }
\end{aligned}
$$

$A_{j}=\frac{N_{l}}{N}$, where $N_{l}-$ the number of pixels with the value of 1 in the image $B_{j}, N-$ total number of pixels in this image;

$v_{j}$ - the average gray pixels of the image $I_{i}$, corresponding pixels with a value of 1 image $B_{i}$;

$N_{8 j}$ - number of 8-connected areas in the image $B_{i}$. This value can be calculated using a known algorithm that allows marking images [15]. It should be noted that in the author's writing segmentation fractal analysis, this paragraph is absent. It was introduced in the algorithm of this paper, as it gave noticeable improvements in the results of the classification.

$D_{j}$ - fractal dimension, calculated from the image $B_{i}$ with the help of box-counting method [16]. This is the most important feature. It describes the complexity of the contour lines of segmented areas.

Advantages of fractal analysis:

1. Images of artificial and natural objects have very distinct fractal dimensions, which allow you to successfully use fractal features to identify artificial landscape changes in photos from space, the discovery of artificial objects in images taken from cameras and other tasks.

2. Regardless of the method used to calculate the fractal dimension, the general view of the histograms is preserved, while the boundaries of the regions are characterized by the same values of the fractal dimension, which makes it possible to identify the different types of textures under study.

Lack of fractal analysis:

1. Processing by the method of fractal analysis does not allow, as a rule, to construct a global fractal model of the entire image.

2. The fractal method of processing image textures is labor-intensive.

The algorithms for finding key points and calculating their descriptor presented in papers $[7,11,14,15]$ were used in the work. The experiment carried out an assessment of the quality and timing of the comparison of two images. The research was conducted on a sample of 80 images. In table 1 the result of a comparative analysis of the search methods for reference points are presented.

Table 1. Analysis of methods for finding reference points

\begin{tabular}{|l|c|c|c|c|}
\hline \multicolumn{1}{|c|}{$\begin{array}{c}\text { Method of finding reference } \\
\text { points }\end{array}$} & $\begin{array}{c}\text { The number of correct } \\
\text { answers }(\%)\end{array}$ & $\begin{array}{c}\text { Number of errors of } \\
\text { the first type (\%) }\end{array}$ & $\begin{array}{c}\text { Number of errors of } \\
\text { the second type (\%) }\end{array}$ & $\begin{array}{c}\text { Average operating } \\
\text { time (in sec.) }\end{array}$ \\
\hline Genetic Algorithm & 84.25 & 5.3 & 10.45 & 5.23 \\
\hline Neural Networks & 52 & 15.4 & 32.6 & 8.45 \\
\hline SIFT & 81 & 10.2 & 8.8 & 1.32 \\
\hline Fractal analysis of textures & 85.7 & 3.3 & 11 & 6.56 \\
\hline
\end{tabular}

Preceding from the conducted research it is suggested:

- When developing marker recognition methods, it is necessary to develop an image preprocessing procedure for forming front marker algorithms under different image acquisition conditions;

- It is expedient to use genetic algorithms on the basis of the best indicators of correct segmentation and low processing times, at the stages of segmentation, but it is necessary to develop functions that correspond to the format of the markers construction;

- Improve existing methods for processing segmentation results based on a criterion base describing a visual model representing a marker.

\section{Conclusion}

As a result of the analysis, the following conclusion can be drawn. The fastest and the most accurate algorithm with key points is the genetic algorithm (average time of the algorithm is 5.23 seconds; the number of correct answers is 84.25). The longest working time is the neural network method - 8.45 seconds, the accuracy of this algorithm is also the lowest -52 .

Another advantage of the point matching algorithm is that if the object goes beyond the frame and then returns again, the program will continue to track this object again. This is supported by algorithms of machine learning. You can also notice that the SIFT calculation works much faster than fractal texture analysis. 
These results suggest that there are currently no methods for recognizing markers that allow for recognition with a high accuracy of less than one unit in a short time.
From our point of view, one of the perspective directions is the use of Royan methods, namely the development of target functions for accurate and fast recognition of images by markers

\section{References}

1. Lyamov, Yu. (2014), "Augmented reality technology" ["Tekhnologiya dopolnennoy real'nosti"], Modern technology and technology, No. 9, available at: http://technology.snauka.ru/2014/09/4567 (last accessed 23.11.2018).

2. Samoilov, A. N, Shevchenko, I. V. (2015), "Methods of reconstructing the contour line of the dislocation of a digital image of Arseny Gaul's plate" ["Metody vosstanovlenija linii kontura dislokacii cifrovogo izobrazhenija plastiny Arsenida Gallija"], EasternEuropean Journal of Enterprise Technologies, Vol. 3, No. 5 (75), P. 9.

3. Ruban, I. V., Shitova, O. V., Vel'chev, K. A. (2008), "The method of localization of objects in the systems of image processing of remote sensing of the eart" ["Metod lokalizatsii ob"ektov v sistemakh obrabotki izobrazheniy distantsionnogo zondirovaniya zemli"], Management, navigation and communication systems, No. 1 (5), P. 35-37.

4. Krig, S. (2016), "Interest Point Detector and Feature Descriptor Survey", Computer Vision Metrics, P. 187-246.

5. Mikolajczyk, K., Schmid, C. (2005), "A performance evaluation of local descriptors", IEEE Transactions on Pattern Analysis and Machine Intelligence, No. 27 (10), P. 1615-1630.

6. Beham, A., Wagner, S., Winkler, S., Affenzeller, M. (2017), "Genetic Algorithms", Encyclopedia of Computer Science and Technology, Vol. 2, P. 469-480.

7. Kass, M., Witkin, A., Terzopoulos, D. (1988), "Snakes: Active contour models", International journal of computer vision, Vol. 1, No. 4, P. 321-331.

8. Kenneth, A De Jong (2006), "Evolutionary computation: a unified approach", MIT press, P. 64-65.

9. Bodyanskiy, Y., Vynokurova, O., Pliss, I., Setlak, G., Mulesa, P. (2016), "Fast learning algorithm for deep evolving GMDH-SVM neural network in data stream mining tasks", IEEE First International Conference on Data Stream Mining \& Processing (DSMP), Lviv (Ukraine), P. 257-262.

10. Kobayashi, M. (2017), "Fixed points of split quaternionic hopfield neural networks", Signal Processing, Vol. 136, P. 38-42.

11. Bodyanskiy, Y. V., Tyshchenko, A. K. , Deineko, A. A. (2015), "An evolving radial basis neural network with adaptive learning of its parameters and architecture", Automatic Control and Computer Sciences, Vol. 49, No. 5, P. 255-260.

12. Zhernova, P., Bodyanskiy, Y. (2018), "Kernel fuzzy clustering of data streams based on the ensemble of neural networks", Innovative Technologies and Scientific Solutions for Industries, No. 4 (6), P. 42-47. DOI: https://doi.org/10.30837/25229818.2018.6.042.

13. David, G. (2004), "Lowe Distinctive Image Features from Scale-Invariant Keypoints", International Journal of Computer Vision, P. $91-110$

14. Geusebroek, J., Smeulders Arnold, van de Weijer Joost. (2012), "An Efficient Algorithm for Fractal Analysis of Textures", 25th SIBGRAPI Conference on Graphics, Patterns and Images, P. 39-46.

15. Ruban, I., Khudov, H., Khudov, V., Khizhnyak, I., Makoveichuk, O. (2017), "Segmentation of the images obtained from onboard optoelectronic surveillance systems by the evolutionary method", Eastern-European Journal of Enterprise Technologies, Vol 5. No. 9 (89), P. 52-54. DOI: https://doi.org/10.15587/1729-4061.2017.109904.

16. Long, M., Peng, F. (2013), "A Box-Counting Method with Adaptable Box Height for Measuring the Fractal Feature of Images", Radioengineering, P. 208-213.

Received 15.01.2019

\section{Відомості про авторів / Сведения об авторах / About the Authors}

Бологова Наталія Миколаївна - Харківський національний університет радіоелектроніки, асистент кафедри електронно-обчислювальних машин, Харків, Україна; e-mail:natalka.bologova@gmail.com; ORCID ID: https://orcid.org/00000001-8927-0055.

Бологова Наталия Николаевна - Харьковский национальный университет радиоэлектроники, ассистент кафедры электронно-вычислительных машин, Харьков, Украина.

Bolohova Nataliia - Kharkiv National University of Radio Electronics, Assistant at the Department of Electronic Computing Machines, Kharkiv, Ukraine.

Рубан Ігор Вікторович - доктор технічних наук, професор, Харківський національний університет радіоелектроніки, проректор з науково-методичної роботи, Харків, Україна; e-mail: ihor.ruban@nure.ua, ORCID ID: https://orcid.org/0000-00024738-3286.

Рубан Игорь Викторович - доктор технических наук, профессор, Харьковский национальный университет радиоэлектроники, проректор по научно-методической работе, Харьков, Украина.

Ruban Igor - Doctor of Sciences (Engineering), Professor, Kharkiv National University of Radio Electronics, Vice-Rector for Scientific and Methodological Work, Kharkiv, Ukraine. 


\section{ДОСЛІДЖЕННЯ МОДЕЛЕЙ ТА МЕТОДІВ ОБРОБКИ ЗОБРАЖЕНЬ ТА ШЛЯХИ ВДОСКОНАЛЕННЯ ТЕХНОЛОГІЙ РОЗПЗНАВАННЯ МАРКЕРІВ В СИСТЕМАХ ДОПОВНЕНОЇ РЕАЛЬНОСТІ}

Предметом дослідження в статті є методи обробки зображень, які виявляють і описують локальні ознаки зображення. Мета роботи - визначення шляхів вдосконалення методів обробки зображень для застосування в технологіях розпізнавання маркерів в системах доповненої реальності. В статті вирішуються наступні завдання: провести аналіз існуючих методів та алгоритмів пошуку об'єктів на двомірних зображеннях для визначення базової технології розпізнавання маркерів в системах доповненої реальності. Аналізуються генетичні, нейронномережні, статистичні та фрактальні методи, а також підходи до реалізації алгоритмів при побудові програмного забезпечення систем доповненої реальності. Отримано наступні результати: проведено огляд i порівняльний аналіз основних відомих алгоритмів детектування ключових точок на зображеннях. Пропонується при розробці методів розпізнавання маркерів необхідно розробити процедуру попередньої обробки зображення для формування алгоритмів фронтального зображення маркера при різних умовах отримання зображень. На стадіях сегментації доцільно використовувати генетичні алгоритми на підставі найкращих показників правильної сегментації та низьких показників часу обробки, але при цьому необхідно розробити функції, які відповідають формату побудови маркерів. Вдосконалити існуючі методи обробки результатів сегментації на основі критеріальної бази що описує візуальну модель, що представляє маркер. Висновки: в результаті проведення аналізу можна зробити наступний висновок. Найшвидшим і точним алгоритмом зі поставленням ключових точок $є$ генетичний алгоритм (середній час роботи алгоритму - 5,23 секунди, кількість правильних відповідей - 84,25). Найтриваліший за часом роботи $є$ метод нейронних мереж $-8,45$ секунд, точність роботи даного алгоритму теж найнижча -52 . Ще одним 3 плюсів алгоритму зіставлення точок те, що якщо об'єкт вийде за межі кадру, а потім знову повернеться, програма буде знову продовжувати відслідковувати цей об'єкт. Цьому сприяють алгоритми машинного навчання. Також можна помітити, що обчислення методом SIFT працює значно швидше фрактального аналізу текстур. Дані результати говорять про те, що в даний час відсутні методи розпізнавання маркерів, що дозволяють з високою точністю ближче до одиниці за короткий час провести розпізнавання. На наш погляд одним 3 перспективних напрямків є використання ройових методів, а саме розробка цільових функцій для точного і швидкого розпізнавання зображення за маркерами.

Ключові слова: доповнена реальність; маркер; безмаркерна технологія; дескриптор; опорні точки; детектор кутів Харіса; генетичні алгоритми; нейрона мережа; SIFT.

\section{ИССЛЕДОВАНИЕ МОДЕЛЕЙ И МЕТОДОВ ОБРАБОТКИ ИЗОБРАЖЕНИЙ И ПУТИ СОВЕРШЕНСТВОВАНИЯ ТЕХНОЛОГИЙ РАСПОЗНАВАНИЯ МАРКЕРОВ В СИСТЕМАХ ДОПОЛНЕННОЙ РЕАЛЬНОСТИ}

Предметом исследования в статье являются методы обработки изображения, которые выявляют и описывают локальные признаки изображения. Цель работы - определение путей совершенствования методов обработки изображений для применения в технологиях распознавания маркеров в системах дополненной реальности. В статье решаются следующие задачи: провести анализ существующих методов и алгоритмов поиска объектов на двухмерных изображениях для определения базовой технологии распознавания маркеров в системах дополненной реальности. Анализируются генетические, нейронносетевые, статистические и фрактальные методы, а также подходы к реализации алгоритмов при построении программного обеспечения систем дополненной реальности. Получены следующие результаты: проведен осмотр и сравнительный анализ основных известных алгоритмов детектирования ключевых точек на изображениях. При разработке методов распознавания маркеров необходимо разработать процедуру предварительной обработки изображения для формирования алгоритмов фронтального изображения маркера при различных условиях получения изображений. На стадиях сегментации целесообразно использовать генетические алгоритмы на основании лучших показателей правильной сегментации и низких показателей времени обработки, но при этом необходимо разработать функции, которые соответствуют формату построения маркеров. Усовершенствовать существующие методы обработки результатов сегментации на основе критериальной базы описывающий визуальную модель, представляющая маркер. Выводы: в результате проведения анализа можно сделать следующий вывод. Самым быстрым и точным методом с постановкой ключевых точек является генетический алгоритм (среднее время работы алгоритма - 5,23 секунды, количество правильных ответов - 84,25). Самый по времени работы является метод нейронных сетей - 8,45 секунд, точность работы данного алгоритма тоже самая низкая - 52. Еще одним из плюсов алгоритма сопоставления точек том, что если объект выйдет за пределы кадра, а затем снова вернется, программа будет снова продолжать отслеживать этот объект. Этому способствуют алгоритмы машинного обучения. Также можно заметить, что вычисления методом SIFT работает значительно быстрее фрактального анализа текстур. Данные результаты говорят о том, что в настоящее время отсутствуют методы распознавания маркеров, позволяющих с высокой точностью ближе к единице за короткое время провести распознавания. На наш взгляд одним из перспективных направлений является использование роевых методов, а именно разработка целевых функций для точного и быстрого распознавания изображения с маркерами.

Ключевые слова: дополненная реальность; маркер; безмаркерная технология; дескриптор; опорные точки; детектор углов Харриса; генетические алгоритмы; нейронная сеть; SIFT. 